\title{
NATIONALISM AND POLITICAL THOUGHTS OF SHEIKH M. ARSYAD THALIB LUBIS (1908-1972)
}

\author{
Mardian Idris Harahap \\ Universitas Islam Negeri Sumatera Utara \\ Jl. Willem Iskandar Pasar V Medan Estate, Medan, Sumatera Utara, 20371 \\ e-mail: mardianidris07@gmail.com
}

\begin{abstract}
This article describes the Nationalism and political thought of Sheikh M. Arsyad Talib Lubis (Tuan Arsyad). Tuan Arsyad's political ideology is religious nationalist in style, and his political thought is characterized as integrism in typology. His political views were inspired by his knowledge and understanding of Islamic sciences (especially fiqh or Islamic law). Sheikh M. Arsyad Thalib Lubis' political ideas and fatwas had a significant impact in instilling a sense of nationalism among Muslim youngsters, particularly in North Sumatra, in fighting colonialism and eradicating Communism. However, his political views on communism were challenged and criticized by Soekarno (the first President of Indonesia) who labelled them as communist phobia and an unethical conduct. Donald E Weatherbee characterized Sheikh M. Arsyad Thalib Lubis' ideas against President Soekarno as a group that engaged in insubordination and posed a threat of punishment.
\end{abstract}

\begin{abstract}
Abstrak: Artikel ini menjelaskan tentang nasionalisme dan pemikiran politik Syekh M. Arsyad Thalib Lubis. Pemikiran politik Syekh M. Arsyad Thalib Lubis memiliki corak nasionalis religius dan tipologi pemikiran politiknya digolongkan kepada tipe integrisme. Pemikiran politiknya dipengaruhi oleh pemahaman dan kedalaman pengetahuannya terhadap ilmu keislaman (khususnya ilmu fikih atau hukum Islam). Pemikiran politik dan fatwa Syekh M. Arsyad Thalib Lubis memiliki pengaruh yang luas dalam membangkitkan semangat nasionalisme para pemuda umat Islam khususnya Sumatera Utara dalam melawan kolonialisme dan memberantas komunisme. Namun, berkaitan dengan pemikirannya tentang komunisme ini mendapat tantangan dan celaan dari Soekarno (Presiden Indonesia pada masa Orde Lama) serta menyebutnya dengan komunis phobia dan suatu perbuatan yang amoral. Pertentangan pemikiran Syekh M. Arsyad Thalib Lubis terhadap Presiden Soekarno ini, diklasifikan oleh Donald EWeatherbee sebagai kelompok yang melakukan pembangkangan dan sebagai resikonya akan dijatuhi hukuman.
\end{abstract}

Keywords: ulama, M. Arsyad Thalib Lubis, Islamic political view(s), religious nationalist, integrism 


\section{Introduction}

In the context of Indonesia, the political role of ulama had been realized in the precolonial, colonial, and imperial eras, as well as pre-and post-independence. ${ }^{1}$ As a manifestation of ulama nationalism, they became a symbol of resistance, particularly during colonialism, in order to achieve independence for the motherland. The triumph of Indonesia in winning independence did not come as a gift, but rather as a result of a lengthy and arduous battle and sacrifice marked by conviction and confidence, as well as a patriotic and unyielding spirit. ${ }^{2}$ To achieve an independent and sovereign unitary state of the Republic of Indonesia, the ulama, martyrs, and combatants were willing to give up their wealth, health, family, and even their entire body and soul. ${ }^{3}$

While not acknowledging the phrases of 'yielding to the circumstance' and the hegemony of the invaders attempting to conquer Indonesia, the Ulama were also struggling to aspire and waken the people to freed themselves from the Western invaders, These Indonesian heroes' sacrifices and hardships were immense and immeasurable in attaining the country's independence. ${ }^{4}$ Their heroism and patriotism thus should be emulated by the current generation. ${ }^{5}$ Meanwhile, it is significant to note that the spirit of resistance to colonialism can be found in the thoughts and action of Sheikh M. Arsyad Thalib Lubis (d. 1972), hereinafter referred to as Tuan Arsyad, in local cases, particularly in North Sumatra.

Tuan Arsyad, born in the twentieth century, was a North Sumatran scholar who not only wrote an important work to inspire resistance to colonialism, but also actively involved in national scale regional-based religious movements and organizations, namely Al Jam'iyatul Washliyah, ${ }^{6}$ as well as an Islamic political party, Masyumi. ${ }^{7}$ The Al Jam'iyatul

${ }^{1}$ Mhd. Syahnan, Asrul Asrul, and Ja'far Ja'far, "Intellectual Network of Mandailing and Haramayn Muslim Scholars in the Mid-19th and Early 20th Century," TEOSOFI: Jurnal Tasawuf Dan Pemikiran Islam 9, no. 2 (2019), https://doi.org/10.15642/teosofi.2019.9.2.257-281.

${ }^{2}$ Mumtazul Fikri, "Transformasi Tradisi Akademik Islam dan Kontribusinya Terhadap Resolusi Konflik Agama di Aceh," Jurnal Confrence Proceedings - ARICIS I, no. 1 (2016): 554.

${ }^{3}$ Mukani, "Ulama Al-Jawwi di Arab Saudi dan Kebangkitan Umat Islam di Indonesia," Jurnal Al Murabbi 2, no. 2 (2016): 227.

${ }^{4}$ Ahmad Hanany Naseh, "Nasionalisme dalam Tinjauan Islam," Jurnal Ulumuddin 4, no. 2 (2014): 15.

${ }^{5}$ Andita Trias Nur Azizah \& Pawito, "Perbandingan Nilai-nilai Patriotisme dalam Film," Jurnal Komunikasi Massa 1 (2015): 2.

${ }^{6}$ For the ideology of this organization, see: Mhd. Syahnan, Ja'far Ja'far, and Muhammad Iqbal, "Ulama and Radicalism in Contemporary Indonesia: Response of Al Washliyah's Ulama on Radicalism," AHKAM: Jurnal Ilmu Syariah 21, no. 1 (2021): 89-110; Ja'far Ja'far, "Al Jam'iyatul Washliyah Dan Pelestarian Akidah Ahl Sunnah Wa Al-Jama'ah Di Indonesia," ISLAMICA: Jurnal Studi Keislaman 14, no. 1 (2019), https://doi.org/10.15642/islamica.2019.14.1.54-81; Ja'far Ja'far. "Respons Al Jam'iyatul Washliyah Terhadap Terorisme," AKADEMIKA: Jurnal Pemikiran Islam 22, no. 1 (2017).

${ }^{7}$ Ja'far Ja'far, “Pemikiran Politik Islamisme Moderat Al Jam'iyatul Washliyah,” Al-A'raf: Jurnal Pemikiran Islam Dan Filsafat 16, no. 2 (2019), https://doi.org/10.22515/ajpif.v16i2.1762. 
Washliyah ${ }^{8}$ organization emerged as a response to the strengthening of Dutch colonialism in North Sumatra with a Christianization projection. ${ }^{9}$ Thus Tuan Arsyad was not only known as one of the scholars who opposed the Christianization movement through colonialist missionaries, ${ }^{10}$ but also a leading scholar ${ }^{11}$ considered to have religious tolerance by some groups, ${ }^{12}$ which were much involved in conducting interfaith dialogue, particularly between Islam and Christianity. ${ }^{13}$

In connection with his battle and attempts to defend the independence of the Republic of Indonesia from the Dutch re-colonization and their allies, Mr Arsyad was noted for his work advocating for a holy jihad against colonialism through his writings entitled Penuntun Perang Sabil (the Guide of Sabil War). ${ }^{14}$ This book discusses the demand for jihad against colonialism that led to his arrest and imprisonment by the government, ${ }^{15}$ which was then controlled by the Netherlands and its allies. ${ }^{16}$ Other than that, he was involved in a variety of governmental security and rescue movements that were framed by ideology and religious orientation to combat colonialism such serving as a Hizbullah soldier, Sabilillah soldier, and Al Washliyah laskar.

In addition to the foregoing, Tuan Arsyad's struggle for Indonesia's independence could also be witnessed in his active participation in suppressing communism's understanding

${ }^{8}$ This organization was founded by Ismail Banda, Abdurrahman Sjihab, M. Arsyad Thalib Lubis and Yusuf Ahmad Lubis. See: Ja'far Ja'far, "Merantau Demi Republik: Kehidupan Dan Perjuangan Ismail Banda (1909-1951)," Islamijah: Journal of Islamic Social Sciences 1, no. 2 (2020): 13661, https://doi.org/10.30821/islamijah.v1i2.7181; Ja'far Ja'far, “Tradisi Intelektual Ulama Mandailing Abad Ke-20: Dedikasi Dan Karya-Karya Yusuf Ahmad Lubis (1912-1980)," Islamijah: Journal of Islamic Social Sciences 1, no. 2 (2020): 225-47, https://doi.org/10.30821/islamijah.v1i3.7342; Ja'far Ja'far, "Ulama Mandailing Awal Abad Ke-20: Gerakan Religius Dan Politik Abdurrahman Sjihab (1910-1955)," Islamijah: Journal of Islamic Social Sciences 1, no. 1 (2020): 1-25, https:// doi.org/10.30821/islamijah.v1i1.7155.

${ }^{9}$ Deliar Noer, Gerakan Moderen Islam di Indonesia 1900-1942 (Jakarta: LP3ES, 1996), 266.

${ }^{10}$ M. Rozali, "Tradisi Dakwa Ulama Al Jam'iyatul Washliyah Sumatera Utara," Jurnal Al Bayan 22, no. 33 (2016): 62. See also Husni Mubarok, "Babak Baru Ketegangan Islam dan Kristen di Indonesia," Studia Islamika 21, no. 3 (2014): 582-583.

${ }^{11}$ B.J. Boland, The Struggle of Islam in Modern Indonesia (Leiden: Springer-Science+Business Media, 1971), 75-76. See also Rusydi Hamka, Pribadi dan Martabat Buya Hamka, (Jakarta: Penerbit Noura, 2016), 302.

${ }^{12}$ Sugeng Wanto, et.al, "Theological Aspect on Ijtihad of M. Arsyad Thalib Lubis' Thought," Journal of Humanities and Social Science 22, no. 6 (2017): 82.

${ }^{13} \mathrm{Al}$ Rasyidin, "Islamic Organizations in North Sumatra: The Politics of Initial Establishment and Later Development," Journal of Indonesian Islam 10, no. 01 (2016): 73-74.

${ }^{14}$ M. Arsjad Thalib Lubis, "Pembelaan Islam Terhadap Serangan Atheisme," in Dokumentasi Muktamar Ulama se-Indonesia di Palembang tanggal 8-11 September 1957 (Palembang: Panitia Kongres Alim Ulama Seluruh Indonesia, 1957).

${ }^{15}$ Ibrahim Alfian, Perang di Jalan Allah: Perang Aceh 1873-1912 (Jakarta: Pustaka Sinar Harapan, 1987), 151.

${ }^{16}$ Sopian, Ilyas \& Roslan Mohamed, "Syekh Muhammad Arsyad Thalib Lubis:Kajian Terhadap Dakwahnya di Medan Sumatera Utara Indonesia," Analytica Islamica 3, no. 2, (2014): 317-318. 
and movement. ${ }^{17} \mathrm{Mr}$. Arsyad was againts any anti-God movements, while President Soekarno at the time granted the Indonesian Communist Party a seat and a role in his government cabinet as well as ertablished the Nasakom (nationalist, religious, and communist) views.v Prior to the September 30, 1965 movement, Mr. Arsyad had been involved in articulating and issuing fatwas on anti-communism and the hidden threats it. He had also prohibited this understanding and movement, as well as stated his disbelief in those who adhere to it and its supporters. ${ }^{18}$

Tuan Arsyad's thoughts and actions are of course informed and motivated by the breadth of his religious understanding, which had also influenced his critical thinking and patriotism, as well as served as the foundation for his nationalism. Attitudes and actions such as these might be capital for the next generation in shaping the nation's character, which has been a major agenda since the beginning of Republic of Indonesia's independence. ${ }^{19}$ For this reason, As a result, it is worthwhile to conduct in-depth research on national political thoughts, socio-political activities, and the influence of Tuan Arsyad's ideas, because his figure can be a remarkable representation how ulama in the regions have made a significant contribution to Indonesia's struggle against colonialism and communism..$^{20}$

\section{Metodhology}

This study employed a qualitative research method, particularly the character studies or individual life history research. ${ }^{21}$ This type of study has a substantial impact on communal life activities, thus was later developed more broadly in higher education. ${ }^{22}$ The existing studies figures have been carried out in two forms. First, as part of the historical approach of the figures concerned. Second, dealing with the topics discussed by the figures concerned. ${ }^{23}$

The data collected in this study are classified into two categories: primary and secondary data. The primary data are works written by Tuan Arsyad. among which are: Penuntun

${ }^{17}$ Kevin William Fogg, "The Fate of Muslim Nationalism in Independent Indonesia," $P h D$, (Dissertation: Yale University, New Haven, 2012), 332.

${ }^{18}$ See also: Ja'far Ja'far, Dewan Fatwa Al Jam'iyatul Washliyah: Sejarah Dan Fatwa-Fatwa (Medan: Dewan Fatwa Al Jam'iyatul Washliyah dan Perdana Publishing, 2020); Ja'far Ja'far, "Respons Dewan Fatwa Al Jam'iyatul Washliyah Terhadap Isu Akidah Dan Syariah Di Era Global," Al-Manahij: Jurnal Kajian Hukum Islam, 2017, https://doi.org/10.24090/mnh.v10i1.919.

${ }^{19}$ Yudi Hartono, "Model Pembelajaran Nilai-nilai Karakter Bangsa di Indonesia dari Masa ke Masa," Jurnal Agastya 7, no. 1 (2017): 34.

${ }^{20}$ Ja'far Ja'far, "Peran M. Arsjad Th. Lubis Dalam Pengembangan Ilmu-Ilmu Keislaman," Dialogia: Jurnal Studi Islam Dan Sosial 18, no. 2 (2020): 355-76.

${ }^{21}$ Arief, Furchan \& Agus Maimun, Studi Tokoh: Metode Penelitian Mengenai Tokoh (Yogyakarta: Pustaka Pelajar, 2005), 1.

${ }^{22}$ Furchan \& Maimun, Studi Tokoh, 6.

${ }^{23}$ Syahrin Harahap, Metodologi Studi Tokoh Pemikiran Islam (Jakarta: Prenada Media Group, 2011), 4. 
Perang Sabil (Guide of Sibil War) published in 1957; Risalat Djaminan Kemerdekaan Beragama dalam Islam (Treatise on the Guarantee of Religious Freedom in Islam) in 1961; Kedudukan Kepala Negara Republik Indonesia Ditinjau dari Sudut Hukum Islam (The position of the Head of State of the Republic of Indonesia from Islamic Law Perspective) in 1967; Ilmu Fiqh (the Science of Fiqh) in 1963, Pembangoen Semangat Perdjoeangan an Article in Pedoman Pemoeda newspaper, January 1946), Pembahasan Disekitar Nuzul-ul Qur-an dan Hari-Hari Peringatan Islam, tahun 1967. The secondary data are in the form of biographies, documents, magazines, newspapers, unstructured in-depth interviews and several research reports in the form of dissertations and other scientific works from experts regarding Tuan Arsyad's biography, thoughts, achievements as well as his struggle activities. These varied data were studied using content analysis according to the object of their respective discussions, and described descriptively using historical and political approaches.

\section{Results and Discussion}

\section{Biography of M. Arsyad Thalib Lubis}

Mr. Arsyad, whose full name is Sheikh Haji Muhammad Arsyad bin Lebai Thalib Lubis, was born in Stabat, Langkat district, about 40 kilometers north of Medan, North Sumatra, in October 1908. ${ }^{24} \mathrm{He}$ was the fifth of eight children born to the couple Lebai Thalib bin $\mathrm{H}$. Ibrahim Lubis and Kuyom Nasution binti Abdullah. Tuan Arsyad was nurtured in a setting with a strong Islamic tradition, as indicated by the term "lebai" connected to his father's name. ${ }^{25}$

During his early childhood, Tuan Arsyad was raised by his maternal grandmother until his enrollment to Stabat's Vervolg School (lower school). In 1917-1922, he continued his studies at the Islamic Madrasah in Stabat and at the Islamic Madrasah in Binjai in 1921-1922. A year later (1923-1924), he pursued his studies at Madrasah 'Ulum al-Arabiyah in Tanjung Balai led by Syekh H. Abdul Hamid Mahmud (1894-1951), a scholar who received higher education at al-Azhar University. Furthermore, from 1925 to 1930, he continued his studies in Madrasah al-Hasaniah in Medan under the supervision of Syekh H. Hasan Ma'sum, ${ }^{26}$ a great ulama from East Sumatra at the time who went on to become Mufti, Imam, and Religious Advisor of the Kingdom of Deli (1884-1937), Syekh H. Hasan Ma'sum (1884-1937), from whom he deepened his knowledge of Qur'anic Tafseer, Hadith, Ushul

${ }^{24}$ H. M. Hasballah Thaib, Syeikh H.M. Arsyad Thalib Lubis Pemikiran \& Karya Monumental (Medan: Perdana Publishing, 2012), 21.

${ }^{25}$ Arifinsyah, "Visi Pluralisme M. Arsyad Thalib Lubis," Peran Moderasi Al-Washliyah, Saiful Akhyar Lubis (ed.) second published (Medan: Univa Press, 2009), 66.

${ }^{26}$ Ja'far Ja'far, “Tarekat Dan Gerakan Sosial Keagamaan Shaykh Hasan Maksum," Teosofi: Jurnal TasawufDan PemikiranIslam 5, no. 2 (2016): 269, https://doi.org/10.15642/teosofi.2015.5.2.269293. 
Fiqh, and Fiqh Science. Tuan Arsyad began his teaching career at Madrasah al-Irsyadiah of Medan in 1926. Four years later, he married Siti Jamaah binti Kamil bin Sampurna, a female from the Deli Malay tribe. From this marriage, he was blessed with eight children, namely, Anisah Fahmi Lubis, Mukhtar Hanif Lubis, Muslim Arif Lubis, Nur Aziah Hikmah Lubis, Khairat Lubis, Husna Lubis, Maisarah Lubis, and Hawari Lubis.

Apart from being a teacher, Tuan Arsyad was also active in journalism as an article writer and a leader for numerous magazines based in Medan. Among his activities in journalism were writing articles for Fajar Islam magazine from 1928 to 1931 and serving as the leading writer of Medan Islam magazine from 1935 to 1942. In 1945, he became the primary author of Dewan Islam magazine and chosen to be an editorial member of alIslam from 1955 to $1957 .{ }^{27}$ In terms of teaching and the educational abilities that had been ingrained in him, he grew and developed along with his broadened knowledge. As a result, the people of Meulaboh (West Aceh) approached him to teach there. In 1931-1932, he taught in Madrasah Al Washliyah Meulaboh as an educator and speaker. ${ }^{28} \mathrm{He}$ returned to Medan in 1932 in order to broaden and develop his expertise, particularly in the field of writing. He returned to teaching in Medan from 1933 until 1945 as a teacher in Madrasah Al Washliyah parts of Ibtidaiyah, Tsanawiyah, and Qism al-'Ali.

In addition to educating and writing for journals and newspapers, Tuan Arsyad was involved in a variety of organizations. He took part in the foundation and formation of the Al Jam'iyatul Washliyah organization in Medan on November 30, 1930. This organization emerged as a result of the initiative and development of Maktab Islamiyah Tapanuli's youth student Debating Club. ${ }^{29}$ He had been an active member, part of the Executive Board, and selected to hold strategic roles in the organization on many occasions since 1956. Indonesian was in a state of emergency due to the Dutch aggression between 945 and 1949, during which Tuan Arsyad and his family lived in exile and moved around Tebing Tinggi and Rantau Parapat areas. Despite this precarious situation, he continued to carry out teaching activities at the al-Qism al-'Ali Madrasah in Tebing Tinggi in 1945-1947.

During the years 1946-1957, Tuan Arsyad held various positions in the area of the Department of Religion (a government agency now known as the Ministry of Religion), both at the central and regional levels of eastern Sumatra (now known as North Sumatra). Among the positions were Staff of the Indonesian Religious Affairs Bureau, Head of the East Sumatra Resident Syariah Court, Head of the East Sumatra Residency Religious Service,

\footnotetext{
${ }^{27}$ Syahrin Harahap \& Hasan Bakti Nasution (ed.), Sejarah Ulama Sumatera Utara (Medan: Majelis Ulama Sumatera Utara, 2013), 259.

${ }^{28}$ H. M. Hasballah Thaib, Universitas Al-Washliyah Medan Lembaga Pengkaderan Ulama di Sumatera Utara (Medan: UNIVA, 1993), 123.

${ }^{29}$ Chalidjah Hasanuddin, Al-Jamiyatul Washliyah, Api dalam Sekam (Bandung: Pustaka ITB, 1988), 34-35.
} 
Head of the Kepenghuluan Section of the Office of Religious Affairs of North Sumatra Province, and Chairman of the Ministry of Religious Affairs of North Sumatra Province. ${ }^{30}$

Since having a background in academics as well as government service, Tuan Arsyad became an active member of the teaching staff who held the highest degree in academia. On January 7, 1954, Tuan Arsyad was named Professor of Jurisprudence and Ushul Fiqh at the Islamic University of North Sumatra (UISU) Medan. Four years later, in 1958 to be precise, he was also appointed Professor in the field of Shari'ah at the University of Al Washliyah (UNIVA) Medan. In 1956, Tuan Arsyad, together with Nasaruddin Latif, were sent by the government to conduct an observation on some communist countries to learn about the portrait of religious life in those countries. The areas visited were the Soviet Union (Russia), Taskent, Samarkand, Stalinrad, Moscow and Leningrad. They returned to Indonesia through other communist areas including the Peking, Rangon and Bangkok. As a result of this visit, Tuan Arsyad wrote a book draft about portraits of the life of Islamic scholars in these Communist countries, unfortunately it was not printed and published because it was removed by his friend in Bandung who promised to print it. On Thursday, 26 June 1972 AC or 23 Jumadil Awal 1392 Hijriyah, Tuan Arsyad passed away after being sick for several days.

\section{Political Thoughts}

In general, Tuan Arsyad's political views were informed by his knowledge of Islamic law, notably fiqh siyasah. ${ }^{31}$ In further discussion it is found that Mr. Arsyad's thought as a whole alludes to the view of fiqh which was indeed his most prominent field, in addition to the problem of comparative religion or christology. ${ }^{32}$ His political thought was also a type of reflection on Islamic law itself, which opened up a lot of room for discussion in this field. Despite the fact that Tuan Arsyad's political ideas were derived from classical fiqh resources, he tried to approach the texts in the context of the current situations and conditions, particularly the participation in the political field in which he was directly involved. ${ }^{33}$ Thus, Tuan Arsyad was not only known as scholar who solely studied religious fields normatively, but also a practitioner of religious doctrine which he perceived as a spirit and incorporated it in every activity he engaged in, including politics. As stated in the previous discussion, Tuan Arsyad was a scholar who was directly involved in the sphere of politics, so his political thinking was notonly a form of understanding Islamic sources that were read and comprehended,

\footnotetext{
${ }^{30}$ Mastuki HS \& M.Ishom El Saha (ed.), Intelektualisme Pesantren: Potret Tokoh dan Cakrawala Pemikiran di Era Keemasan Pesantren, Third Published (Jakarta: Diva Pustaka, 2006), 24.

${ }^{31}$ Masykuri Abdillah, "Epistemologi Fikih Siyasah," Ahkam Jurnal Ilmu Syariah 12, no. 1 (2012), 27.

32 Ilyas \& Mohamed, "Syekh Muhammad Arsyad Thalib Lubis," 315.

${ }^{33}$ Zulkifli, "The Ulama in Indonesia: Between Religious Authority and Symbolic Power," MIQOT XXXVII, no. 1 (2013), 181.
} 
but also inspired by his position as a political fighter who directly took part in achieving, defending, and filling the independence of the Republic of Indonesia.

\section{Jihad and the War against Colonialism (Sabil War)}

According to Tuan Arsyad, war is carried out in Islam based on the principles of Surah Al Hajj verses 39-40 and Surah Al Baqarah verse 190 of the Quran, explaining the reasons such as: first, the cause for the war is to safeguard and defend religious freedom, including the freedom to practice and broadcast it. Second, the Muslims must protect themselves against opposing strikes. ${ }^{34}$ Meanwhile, Muhammad Khudari Bek, as described by Tuan Arsyad, indicated that the Muslims were allowed to fight because of two factors: firstly, to defend themselves from enemy attacks, and secondly, to defend da'wah (Islamic broadcasting) against those who intend to slander the believers. ${ }^{35}$ The purpose of this slander is to torture people who believe in order to persuade them to abandon their religion or to prevent people from accepting Islam, as well as to prohibit preachers and preachers from giving religious invitations or lectures. ${ }^{36}$

According to Mr. Arsyad, the sabil war is a summation of the word sabilillah battle, which derives from Allah's revelation in the Qur'an surah al-Baqarah verse 190, which says:

"And fight you in the way of Allah"

This verse refers to Allah's command to battle in His way, to exalt His religion and exalt His words (kalimatullâh). ${ }^{37}$ The following is Tuan Arsyad's interpretation of kalimatullah (Allah's words), as quoted from al-Hââfidz Ibn Hajar al-'Asqalânî’s opinion. ${ }^{38}$

Allah's call to Islam is to raise the call of Allah who invites people to Islam so that Allah's calls and invitations get a high and respectable place and are free from various obstacles. Next Ibn Hajar ${ }^{39}$ said:

Allah's call to Islam is to elevate His call to those who are invited to Islam, so that Allah's calls and invitations get a high and respectable place and barrier-free. Ibn Hajar ${ }^{40}$ went

\footnotetext{
${ }^{34}$ M. Arsjad Thalib Lubis, Risalat Djaminan Kemerdekaan Beragama dalam Islam second published (Medan: Firma Islamyah, 1961), 23-25.

${ }^{35}$ Muhammad Khudari Bek, Tarikh Tasyri' al-Islami (Beirut: Dar al-Fikr, 1995), 35.

${ }^{36}$ M. Arsjad Thalib Lubis, "Pembelaan Islam Terhadap Serangan Atheisme", 10. See also Masjoemi Priangan, Djihad dan Qitaal (Bandung: Masjoemi Bah. Penerangan Priangan, 1946), 9.

${ }^{37}$ M. Arsjad Thalib Lubis, "Pembelaan Islam Terhadap Serangan Atheisme", 14.

${ }^{38}$ Ibn Hajar Al-Asqalani, Fath al-Bârî Syarh Shahîh $\underline{h}$ al-Bukhârî, juz VI (Beirut: Dar alMa'rifah, 1960), 28.

${ }^{39}$ Al-Asqalani, "Fath al-Bari", 29.

${ }^{40}$ Al-Asqalani, "Fath al-Bari".
} 
on to say: "And included in the intention to exalt Allah's sentence is to seek the pleasure of Allah, seek his reward and demand to destroy his enemies."

From Islam perspective, Wars, including the Sabil war could only be led due to particular reasons, as follows: (1) can magnify kalâmullâh if getting victory; (2) seeking and expecting the pleasure of Allah; (3) fighting the enemies of Allah so that they may perish. ${ }^{41}$

When the Dutch and their allies came to colonize and control Indonesia, all Muslims residing in the nation's territory should refuse their invasion as they were all considered enemies according to Islamic law. Muslims are obliged to establish a battle line and devise ways to combat and expel intruders. The restoration of the Dutch to power in Indonesia signifies that they had control over our right to enforce Islamic rules and our access to the products of our motherland.

With the arrival of the colonizers, Tuan Arsyad firmly believed that Indonesian Muslims' right to freedom in carrying out Islamic law and conveying Islamic calls or syi'ar would be limited and halting. Muslims could not do what they should as the power was in the hands of the colonizers. The product of the homeland could no longer be enjoyed and used entirely for the benefit of the nation as it was divided with the Dutch who received most of the benefit. It would be a different story if Indonesian people had full control over those products, which definitely bring prosperity to the livelihoods of Indonesian people, particularly Indonesian Muslims. As a consequence, Islam would also grow more sporadically. All religious interests that require money and other supports would easily be fulfilled and facilitated, which at the end would help spread Islam as a religion as well as elevate kalimatullâh. ${ }^{42}$

Tuan Arsyad also proclaimed that the war against the Dutch was a battle blessed by Allah the Almighty because its purpose was to exalt Kalâmullâh and uphold Islam, which is considered fardu 'ain (closing to God, following the teachings of Prophet Muhammad) from Islamic law perspective. ${ }^{43} \mathrm{He}$ furthermore stated that the Dutch as the invaders who wanted to control Indonesian homeland were considered kafir harbi, referring to people who could be fought against in war. The Dutch had committed tyrannical acts against the rights of Indonesian people as an effort to seizing and possessing the rights of Muslims, thus they should be seen as the enemies of Allah. ${ }^{44}$ Tuan Arsyad added that anyone who participated in the war against the Dutch colonialists with sincere intentions, meant to exalt kalâmullâh, seek merit, seek Allah's favor, and intend to destroy Allah's enemies, were believed to do a fight in the way of Allah (jihâd fi sabîlillâh), thus if he was killed during the fight, he would be memorized as a martyr granted heaven as his place. ${ }^{45}$

\footnotetext{
${ }^{41}$ Lubis, "Pembelaan Islam Terhadap Serangan Atheisme", 15-16.

${ }^{42}$ Lubis, "Pembelaan Islam Terhadap Serangan Atheisme", 15-16.

${ }^{43}$ Lubis, "Pembelaan Islam Terhadap Serangan Atheisme", 21.

${ }^{44}$ Lubis, "Pembelaan Islam Terhadap Serangan Atheisme", 23.

${ }^{45}$ Lubis, "Pembelaan Islam Terhadap Serangan Atheisme", 23.
} 
Tuan Arsyad's political thoughts in relation to defending the country and its gained independence from the colonialism of the Dutch and their allies were the manifestation of the spirit of patriotism and nationalism framed with Islamic ideology and values. These political thoughts were originated from an understanding of fiqh, which was mostly derived from Syafiiyah school of thought. ${ }^{46}$ His reference or literature on ideas and thoughts were based on the chapters of jihad discussing the related issues of war. The Syâfiiyah jurisprudence books used as references include the followings; Tuhfat al-Muhtâj by Ibn Hajar al-Haitâmî (d. 973 H.), Mughni al-Muhtâj by Muhammad al-Khâthib al-Syarbini (d. 977 H.), Nihâyah al-Muhtâj by Syihâbuddîn al-Ramli (d. 848 H.), Syarh Minhâj al-Thâlibîn by Jalâl al-Dîn al-Mahalli (d. 864 H.), Fath al-'Aziz by 'Abd al-Karîm al-Rafiî (d. 623 H.), al-Majmu' (Syarh al-Muhazzab) by Abû Zakaria Muhyiddîn al-Nawawî (d. 676 H.), Asnal Mathalib and Fath al-Wahhâb by Zakaria al-Anshârî (d. 926 H.), Hâsyiyah Fath al-Qarîb by Ibrâhîm al-Baijuri (d. 1276 AH.), I'ânah al-Thâlibîn by Abu Bakar Syathâ' (d. 1310 H.), al-Adzkâr by Abû Zakaria Muhyiddîn al-Nawawî (d. 676 H.), and some others.

Tuan Arsyad wrote down his political thoughts regarding ethics or guidance in war (or known as Sabil war) to fulfill his colleagues' and fellow Muslims' the wishes and requests during the critical times when the Dutch and their allies planned to recolonize and reclaim the independence of the Republic of Indonesia. His works on war guidance was also dedicated to the war troops as the members of the Sabilillah war troops such as al-Mujahidin, Hizbullah, Laskar Muslimin Indonesia (the Indonesian Muslim army) and others who were already precautious and alarmed mode to defend Indonesian independence in order to uphold kalâmullâh. ${ }^{47}$

\section{Resistance to Communism}

In connection with Muslims' anticipation and attitude towards Communism ideology and movement, Tuan Arsyad suggested that Muslims strive to change their fate in order to become caliphs on earth, thus they would not become objects of communism with their philosophy of materialism, anti-religion and denial of the existence of God, negation of individual rights, dictatorship, and elimination of kinship ties. He further reminded Muslims to learn and master science and technology and create a generation of ^ulil albâb through the establishment of Islamic universities and colleges in Indonesia. ${ }^{48}$ In responding the latent danger of communism and the nation's critical state with the emergence of various rebellions in many regions, religious scholars throughout Indonesia held an Ulama conference in

${ }^{46}$ Ja'far Ja'far, “Peran Al Jam'iyatul Washliyah Dalam Merevitalisasi Madhhab Shafi'i Di Era Kontemporer," Justicia Islamica 13, no. 1 (2016), https://doi.org/10.21154/justicia.v13i1.451.

${ }^{47}$ Lubis, "Pembelaan Islam Terhadap Serangan Atheisme", 7.

${ }^{48}$ Usman Pelly, "Arsyad Thalib Lubis: Ideolog Masyumi,", H. M. Hasballah Thaib, Syeikh H. M. Arsyad Thalib Lubis Pemikiran \& Karya Monumental (Medan: Perdana Publishing, 2012, p. 85-86. 
Palembang on 8-11 September 1957. On this occasion, Tuan Arsyad delivered a proceeding paper entitled, "Defending Islam against Atheism Attacks". All Muslim scholars, according to him, must have a firm and courageous attitude in expressing their stance and provide guidance in stemming and opposing the currents of atheism and communism in order to save Islam and Muslims.

In Tuan Arsyad's view, Atheism is a notion of not believing in God or denying the existence of God, also known as anti-God understanding. ${ }^{49}$ It is stated in al-Qur'an surah al-Jâtsiyah verses 23-24 that this anti-God notion had also existed at the time of the prophet Muhammad. From a historical perspective, the notion of anti-God is constantly present in the journey of worldly life. Some is active while some other is rather passive without having any activities. One of the many ideas classified as anti-God is the Dahri, Vrijdenker group. To sum up, According to Tuan Arsyad, Communism could be named as the only anti-God notion extremely dangerous to religious people, particularly when this ideology is applied with coercion and full of violence. ${ }^{50}$

Tuan Arsyad argued that the communist atrocities in Indonesia could be seen from a history filled with blood, through which Kyai and religious leaders were slaughtered during the communist rebellion in Madiun in September 1948. Communism is a form of imperialism with a cruel final objective to take over the power of a country through various methods and efforts and would never stop before achieving it. They will not hesitate to infiltrate into religious groups by making us their religious symbols and behave like defenders and lovers of those religions. Tuans Arsyad also opined that they would utilize the freedom of expression and expressing opinions embraced by democratic countries as their weapon to spread and develop their understanding, views, and objectives either through written and oral forms.

Having understood the reality, movement and goals of Communism, Tuan Arsyad further proposed an anticipation and some efforts that is critically important to make to overcome and prevent the attacks of this anti-God ideology. This proposal is the conclusion of his plenary talk about Communism and anti-God ideology delivered at the congress of Alim Ulama in Palembang which contained the following points:

a. There is a need for a fatwa to be issued regarding anti-God ideology which could be used as a guideline for Muslims;

b. Muslims should have one vision and mission in responding to adherents of anti-God ideas;

c. It is necessary to establish an organizational body specifically dealing with anti-God or Communism in terms of its development, movements, attacks and tactics;

\footnotetext{
${ }^{49}$ Lubis, "Pembelaan Islam Terhadap Serangan Atheisme", p. 6.

${ }^{50}$ Lubis, "Pembelaan Islam Terhadap Serangan Atheisme", 7.
} 
d. A cooperation with religious organizations both at home and abroad should be set, especially in addressing the latent dangers of anti-God and Communism ideology and movements;

e. A recommendation should be made for the government to issue a law regarding the prohibition of anti-God establishment or Communism-oriented parties or organizations in the territory of the Republic of Indonesia;

f. It is not permissible for groups or people who have anti-God views to take part in or hold power in government agencies in Indonesia;

g. It is hoped that Kyais and religious leaders provide good examples and role models to the public;

h. In educational field in particular, teaching and culture for children, adolescents and adults need special attention in the following ways: first, increase the establishment of religious schools; second, include religious studies, especially those related to divinity; third, conduct recitations through majelis ta'lim and regular recitation; fourth, increase the number of lectures, tablighs and recitations discussing religion, especially on divine science; fifth, make urgent efforts to open higher education institutions of Islamic orientation in every province throughout Indonesia; sixth, increase the publication of books, newspapers, magazines and dissemination through electronic media with religious spirit in educating the public, either children, adolescents and adults about religion and the dangers of anti-God and communism understanding. ${ }^{51}$

Those eight points outline Tuan Arsyad's thoughts and understanding of what is meant Communism and Atheism which can destroy the foundations of religious life in Indonesia. He also provided some suggested method to anticipate and overcome the dangers and tactics of Communists and Atheists. However, with regard to his thoughts on Communism, he was challenged and criticized by Soekarno (the President of Indonesia during the Old Order) who called his ideas as a communist phobia and an immoral act. In this case, President Soekarno's had a policy of not compromising with those who could not accept his frame of mind. Donald E. Weatherbee described Soekarno's position as a balancer of groups of interest fighting over position. In terms of determining the size of an interest group that is still loyal to Soekarno's position as a mediator, he sets ideological boundaries. As long as it was not beyond the established ideological boundaries, it would be seen as a dialogue partner, but if it had gone out of its ideological boundaries, then the group would automatically be considered to have deviated, thus punishment would automatically be imposed on it.

${ }^{51}$ Lubis, "Pembelaan Islam Terhadap Serangan Atheisme”, 14-15. 


\section{Human Rights on Freedom of Religion and Interaction}

Freedom to embrace and practice religion is a matter of importance for religious people as what Tuan Arsyad firmly believed. Violation against the freedom of religion often causes undesirable impacts. A government wishing to revive an atmosphere of harmony, security and peace in the midst of a plurality of religions must have a firm guarantee and serious attention such freedom. Broadly speaking, the guarantee of religious freedom includes two things, first, the guarantee of freedom to embrace a religion and second, the guarantee of freedom to practice all religious teachings.

In his discussion of the principle of religious freedom, Mr Arsyad denied the accusations from some people and non-Muslims who opined that Islam was spread with the sword (warfare) to force people to convert to that religion. ${ }^{52} \mathrm{Mr}$. Arsyad emphasized that the principles of freedom of religion had been guaranteed in Islamic law, thus the very first Islamic teaching that must be instilled and implemented is faith (belief in the oneness of Allah and the apostolate of the Prophet Muhammad and all his teachings), and all of this is a matter of heart.

True faith cannot be realized from an element of compulsion or coercion. Faith come from trust in the heart that grows out of sincere conviction. Therefore, according to Mr. Arsyad, Islam does not allow compulsion in faith, because cooercion will only make someone a hypocrite (i.e. a person who pretend to have Islam as their religion, someone who at birth appears to be a believer because he acknowledges the oneness of God and the apostolate of the prophet Muhammad with his tongue and at certain times when there is a need, they carry out religious orders, but deep inside their heart they do not believe at all). Coercion against someone equals to forcing someone to lie by making a confession that is untrue and which is not in accordance with one's conscience. This coercion will not result in the increase of the number of brothers in the faith, but rather create more of enemies in blankets. ${ }^{53}$ Tuan Arsyad advised Muslims should never force people of other religious belief to embrace Islam as a way to implement their faith and to uphold the religious teachings that they believe. Al-Qur'an is the only holy book that teaches about freedom of religion. Long before many nations declared freedom of religion as a human right in their constitution, AlQur'an had declared it dozens of centuries earlier.

Mr. Arsyad further stated that the religion of Islam has set a benchmark that will be used as the basis for the pattern of relations between Muslims and non-Muslims, namely the realization of a lifestyle in a safe and peaceful atmosphere in terms of goodness and for the sake of upholding justice and avoiding hatred and war as much as possible. This basic standard will always be maintained by Muslims as long as other parties, namely

${ }^{52}$ M. Arsjad Thalib Lubis, Risalat Djaminan Kemerdekaan Beragama dalam Islam second published (Medan: Firma Islamiyah, 1961), 3-4.

${ }^{53}$ Lubis, "Risalat Djaminan", 6. 
non-Muslims, do not commit crimes against Muslims, such as carrying out attack and expelling them from their own hometowns. If these actions are carried out, Muslims can take reaction in order to defend themselves and their honor, but not to force others to embrace Islam. ${ }^{54}$ Tuan Arsyad also explained that the pattern of relations between Muslims and non-Muslims had been established based on three bases, namely: living in peace; doing good to people of different religions; and enforcing law and justice. ${ }^{55}$ Based on these three principles, Tuan Arsyad believed that a safe and peaceful society can be formed and fostered in the midst of human life.

\section{Pancasila dan Its Interpretation}

The establishment of Pancasila as the ideology or foundation of the Indonesian state is inextricably linked to tough and lengthy scholarly debates and arguments between the two major streams of thought identities, Islamic nationalist and secular nationalist (religious neutral nationalist). The former was represented by M. Nasir whereas the latter by Soekarno. After a long debate, Islamic nationalists agreed to embrace Pancasila as the official philosophy, with the caveat that the interpretation not contravene the Islamic ideal of tauhîd (monotheism). ${ }^{56}$

Tuan Arsyad urged that the interpretation of Pancasila be in accordance with Islamic tauhid.Although he initially desired a state ideology based on Islam, as the ideological debate progressed, he accepted the Pancasila ideology for the benefit and integrity of the Republic of Indonesia, on the condition that its interpretation and translation be consistent with or inextricably linked to Islamic values. Prior to providing his interpretation of Pancasila principles, Tuan Arsyad presented a glimpse by encouraging people to reflect on the state of this independent country. Indonesia, as a country that earned independence as a consequence of its people's struggle and sacrifice, was still building and monitoring citizen loyalty, but it already had the strong foundations of a real state aimed at upholding the Pancasila ideology. The Indonesian people, on the other hand, wanted to see how Pancasila's values were put into effect. ${ }^{57}$

Tuan Arsyad further reminded that in article 29 of the 1945 Constitution in the Preamble and Chapter XI, it is clearly stated that the Republic of Indonesia was based on the Belief in the one and only God, which was also mentioned in the first principle of Pancasila, Ketuhanan Yang Maha Esa. The official constitutional understanding of the word "Esa" had not been nationally agreed upon. As a result, according to Tuan Arsyad, the constitution's provisions

${ }^{54}$ Lubis, "Risalat Djaminan", 30.

${ }^{55}$ Lubis, "Risalat Djaminan", 31.

${ }^{56}$ Muhammad Natsir, Capita Selekta 2, second published (Jakarta: PT. Abadi and Yayasan Capita Selekta, 2008), 203-211.

${ }^{57}$ M. Arsjad Thalib Lubis, Kedudukan Kepala Negara Republik Indonesia Ditinjau dari Sudut Hukum Islam (Medan: Pustaka UNIVA, 1967), 58. 
should be consistent with the beliefs of Indonesia's Muslim majority, because Islam teaches that God is the One, in the sense that there is no God other than Allah..$^{58}$ The official interpretation of the word "Esa" in the constitution had not been conventionally agreed on. Therefore, according to Tuan Arsyad, the provisions of the constitution should be in accordance with the beliefs of the Muslim community, as the majority in Indonesia, because the religion of Islam teaches that God is the One, in the sense that there is no God other than Allah. ${ }^{59}$ According to Islam, all prophets sent by God in the past taught and preached the idea that there is only one God. When Muhammad was called to become an apostle, he continued to teach and preach the same message, emphasizing that Allah is the One and Only God. ${ }^{60}$

The official state interpretation of the first precepts and article 29 verse 1 turned out to be different from what Tuan Arsyad understood. The first principle is interpreted by the state according to its religious views and is founded on just and civilized humanity, but Tuan Arsyad interpreted it as Tauhid, which was adapted to Islamic teachings and is antithetical to other religious teachings. The state claims that citizens' understanding and believe in Almighty God is a personal affair, but Tuan Arsyad argued that state officials must conduct governance based on Almighty God's belief and understanding in line with Islamic teachings.

Furthermore, the precepts that Mr. Arsyad discussed focused on social justice, namely Keadilan Sosial bagi Seluruh Rakyat Indonesia (Social justice for all the people of Indonesia). In this case, he believed that people would pay close attention on how government officials implement this principle. It was not possible for the leaders who live in luxury to take care their people living in poverty. He questioned how a leader could eat a delectable dinner when the people he leads were grieving and groaning in hunger beside him. As an analogy, Tuan Arsyad illustrated a mother or a father who loves their children would not be able to drink even a sip of cold, refreshing water when finding out that the children were lying in front of her/his room because of thirst. A loving parent with affection for their children would never be able close their eyes to sleep soundly lying in a mosquito net, while they know that their children were still lying outside surrounded by mosquitoes. ${ }^{61}$

Tuan Arsyad emphasized on two concepts in interpreting Pancasila's ideology: Ketuhan yang Maha Esa and Keadilan Sosial bagi Seluruh Rakyat Indonesia. It is understandable that the question of 'aqîdah and monotheism was a major concern at the time, especially in light of the growth of anti-God communism, as well as the poor status of the people and the existence of significant social gaps between the people and the governmental apparatus. Tuan Arsyad's view of Pancasila was inextricably linked to his understanding of the Prophet

\footnotetext{
${ }^{58}$ M. Arsjad Thalib Lubis, Keesaan Tuhan menurut Adjaran Kristen dan Islam, third published (Jakarta: Hudaya, 1969), 5.

${ }^{59}$ Lubis, "Keesaan Tuhan menurut Adjaran Kristen dan Islam”, 5.

${ }^{60}$ Lubis, "Keesaan Tuhan menurut Adjaran Kristen dan Islam", 9.

${ }^{61}$ Lubis, Kedudukan Kepala Negara, 59.
} 
Muhammad's teachings and practices in his fight to enhance the dignity and degree of his people. He believed that the Prophet's advice was always respected and obeyed by his followers because the Prophet put it into practice in his own life and set an example in the first place. ${ }^{62}$

\section{Head of State and the Title of Waliy al-Amr al-Dharuri bi al-Syaukah}

Tuan Arsyad's political views are further exemplified by his perception of the role and existence of the head of state in Islam. ${ }^{63}$ In other words, Tuan Arsyad used his understandings of the head of state in Islam to evaluate the head of state in Indonesia. ${ }^{64}$ Although he recognized that Indonesia is not an Islamic state, he always tried to see Indonesian as a state through the lens of Islam, in this case as a form of state that is not anti-Islam. Therefore, Tuan Arsyad attempted to contextualize the sources of Islam that he understood in the context of the Indonesian nation, so that the concept that comes from fiqh that he understood would not be rigidly applied, because Tuan Arsyad was always trying to see jurisprudence ideas in a broader framework. Tuan Arsyad's contextual thought was, of course, tied to his activities, which include not just preaching, but also being intimately involved in any political movement that arose during his lifetime. ${ }^{65}$

Tuan Arsyad explained various provisions had been specified in Jurisprudence in the process of selecting and/or electing the head of state. The first is bai'ah Ahl al-Hall wa al-'Aqd, which is based on the approval and recognition of loyalty to leaders who have been appointed as imams. ${ }^{66}$ Second, is istikhlâf referring to the procedure of selecting/electing a head of state through a will or similar document executed by the previous head of state in order to designate the head of state after his death. The third is istila', which means to conquer and control. Istila' refers to a situation in which a person appoints himself as a head of state by subduing the population, either with their own strength or with the use of military force.

The classification or order of degrees is important for a better understanding of the Islamic state's leader. According to Ibn Hajar al-Haitami's perspective, there are four degrees or classifications of the head of the Islamic state: first, Imam al-a'zham, which refers to the leader of the Islamic state who is selected by one of the procedures described and has met the requirements as an Imam al-a'zham. Emergency Imam, which is the second classification,

${ }^{62}$ Lubis, Kedudukan Kepala Negara, 59.

${ }^{63}$ Ja'far Ja'far, "Al Jam'iyatul Washliyah Dan Kepemimpinan Non Muslim Dan Perempuan," AHKAM: Jurnal Ilmu Syariah 17, no. 2 (2017), http://journal.uinjkt.ac.id/index.php/ahkam/ article/view/5204.

${ }^{64}$ Lubis, Kedudukan Kepala Negara, 4-5.

${ }^{65}$ M. Rozali, "Muhammad Arsyad Thalib Lubis (1908-1972): Ulama yang Membesarkan Al Jam'iyatul Washliyah," Jurnal Studi Multidisipliner 5, no. 1 (2018): 7-8.

${ }^{66}$ H. Kadenun, "Kedudukan Ahl al-halli wa al-Aqdi dalam Pemerintahan Islam," Qalamuna 11, no. 2 (2019): 90. 
refers to the appointment of a leader in an emergency circumstance based on need or desire. If no one meets the requirements of Imam al-a'zham, a person with less qualifications can be appointed as Imam al-a'zham, which is known as an Emergency Imam. An Emergency Imam is an Imam who is less qualified but has been appointed because of a necessity (hajat) or an emergency. ${ }^{67}$

The third classification, waliy bi al-syaukah, refers to a guardian or ruler who wields power through coercion. The ruler of state is called a waliy bi al-syaukah because he obtains authority through the istila' although the criteria of Imam al-a'sham are not met. Tuan Arsyad further described that there are two types of heads of state who gain power through the istila' route: (1) a head of state who meets the criteria for becoming an Imam al-a'sham, and (2) a head of state who does not meet the criteria for becoming an Imam al-a'zham, but only becomes a person in power through syaukah, namely wali bi al-syaukah. ${ }^{68}$

The fourth classification is $d z u$ syaukah, which means "powerful or authoritative person." Dzu syaukah refers to the head of the ruling state who is obeyed and followed by his instructions, even if the head of state is not Muslim and the area where he leads is not an Islamic territory. Even rebel leaders who have influence in the area and their supporters can be referred to as $d z u$ syaukah. ${ }^{69}$

Tuan Arsyad explained that after understanding the procedure for appointing a legitimate head of Islamic state and what his or her duties and functions are under Islamic law, one can conclude that the President of the Republic of Indonesia at that time, President Soekarno (d. 1970), was not classified as either Imam al-a'zham, Emergency Imam, or Waliy bi al-Syaukah. All of these official terms are reserved for the ruler of an Islamic state who serves as a substitute for the Prophet Muhammad in upholding and maintaining Islamic syari'at, while President Soekarno pledged to preserve the Republic of Indonesia's 1945 Constitution and carry out all of its provisions that are not based on Islamic laws and regulations.

Finally, Tuan Arsyad stated that the head of state of the Republic of Indonesia was observed in accordance with the recurring conditions and situation, which he described as " $d z u$-syaukah." The term of $d z u$-syaukah given by fuqahâ' in fiqh texts can be applied to the Republic of Indonesia's head of state. In this context, the appointment of Magistrate Guardian in force in Indonesia was lawfully valid because it was appointed by dzu-syaukah, not Waliy al-Amri al-Dharuri bi al-syaukah, as proclaimed in the decree of by the minister of religion. ${ }^{70}$ Tuan Arsyad then clarified that the appointment of a Magistrate guardian was not limited only to the Imam or waliy al-Amri as defined by syara', but may also be

\footnotetext{
${ }^{67}$ Lubis, Kedudukan Kepala Negara Republik Indonesia, 11.

${ }^{68}$ Lubis, Kedudukan Kepala Negara Republik Indonesia, 11-12.

${ }^{69}$ Lubis, Kedudukan Kepala Negara Republik Indonesia, 12.

${ }^{70}$ Lubis, Kedudukan Kepala Negara Republik Indonesia, 18.
} 
carried out by one of the following officials: 1 . Imam al-A'zham or his Na'ib; 2. Imam alA'zham or his Na'ib; 3. Dzu Syaukah; 4. Ahl al-Hall wa al-Aqd. If the Imam or Na'ib is not present in a given area or region, $d z u$-syaukah may appoint a Magistrate guardian. If no $d z u$-shakah is available, Ahl-al-Hall wa al-Aqd may appoint him.

\section{Conclusion}

Based on the preceding discussion, it is possible to conclude that Tuan Arsyad's political thinking is inextricably linked to his comprehension and depth of knowledge of Islamic studies, particularly Islamic law and the science of jurisprudence. His political thoughts are summarized as follows:

First, love for the homeland and patriotism based on Islamic values are manifestations of nationalism; second, state independence and sovereignty are part of human rights, whereas imperialism and colonialism are oppression and deprivation of human rights; and third, ideologies, movements, and governments oriented towards communism and atheism are illegal and incompatible with the people and the government's ideology in the Republic of Indonesia. Fourth, in anticipation of this Communism understanding and movement, the Indonesian people, particularly Muslims, must be leaders in government so that they do not become objects of Communism. They also need to master science and technology and create a generation of ulul albab (Muslim scholars) through the establishment and expansion of universities and colleges. Islamic education in Indonesia, as well as the publication of books, periodicals, newspapers, and articles, is used to educate the public about information and the perils of Communism and Atheism. Tuan Arsyad was one of the academicians who proposed enacting anti-Communism legislation and the banning of the PKI.

\section{References}

Abdillah, Masykuri. “Epistemologi Fikih Siyasah.” Ahkam Jurnal Ilmu Syariah 12, no. 1, 2012.

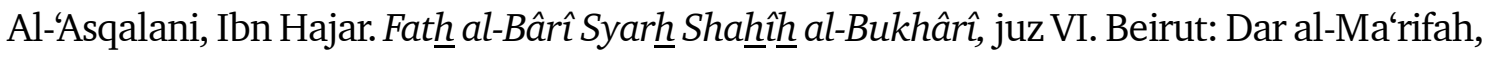
1960.

Alfian, Ibrahim. Perang di Jalan Allah: Perang Aceh 1873-1912. Jakarta: Pustaka Sinar Harapan, 1987.

Al Rasyidin. "Islamic Organizations in North Sumatra: The Politics of Initial Establishment and Later Development." Journal of Indonesian Islam 10, no. 01, 2016.

Arifinsyah. "Visi Pluralisme M. Arsyad Thalib Lubis." Peran Moderasi Al-Washliyah, Saiful Akhyar Lubis (ed.) second published. Medan: Univa Press, 2009.

Azizah, Andita Trias Nur \& Pawito. "Perbandingan Nilai-nilai Patriotisme dalam Film." Jurnal Komunikasi Massa 1, 2015.

Bek, Muhammad Khudari. Târîkh Tasyri‘ al-Islâmi. Beirut: Dâr al-Fikr, 1995. 
MIQOT Vol. 45 No. 1 January-June 2021

Boland, B.J. The Struggle of Islam in Modern Indonesia. Leiden: Springer-Science+Business Media, 1971.

Fikri, Mumtazul. "Transformasi Tradisi Akademik Islam dan Kontribusinya Terhadap Resolusi Konflik Agama di Aceh,” Jurnal Confrence Proceedings-ARICIS 1, no. 1, 2016.

Fogg, Kevin William. "The Fate of Muslim Nationalism in Independent Indonesia" $\mathrm{PhD}$. Dissertation: Yale University, New Haven, 2012.

Furchan, Arief \& Agus Maimun. Studi Tokoh: Metode Penelitian Mengenai Tokoh. Yogyakarta: Pustaka Pelajar, 2005.

H., Kadenun. "Kedudukan Ahl al-halli wa al-Aqdi dalam Pemerintahan Islam." Qalamuna 11, no. 2, 2019.

Hamka, Rusydi. Pribadi dan Martabat Buya Hamka. Jakarta: Penerbit Noura, 2016.

Harahap, Syahrin \& Hasan Bakti Nasution (ed.). Sejarah Ulama Sumatera Utara. Medan: Majelis Ulama Sumatera Utara, 2013.

Harahap, Syahrin. Metodologi Studi Tokoh Pemikiran Islam. Jakarta: Prenada Media Group, 2011.

Hartono, Yudi. "Model Pembelajaran Nilai-nilai Karakter Bangsa di Indonesia dari Masa ke Masa." Jurnal Agastya 7, no. 1, 2017.

Hasanuddin, Chalidjah. Al-Jamiyatul Washliyah: Api dalam Sekam di Sumatera Timur. Bandung: Pustaka ITB, 1988.

HS, Mastuki \& M.Ishom El Saha, (ed.). Intelektualisme Pesantren: Potret Tokoh dan Cakrawala Pemikiran di Era Keemasan Pesantren, Third Published. Jakarta: Diva Pustaka, 2016.

Ilyas, Sopian \& Roslan Mohamed. "Syekh Muhammad Arsyad Thalib Lubis:Kajian Terhadap Dakwahnya di Medan Sumatera Utara Indonesia," Analytica Islamica 3, no. 2, 2014.

Ja'far, Ja'far. “Al Jam'iyatul Washliyah Dan Kepemimpinan Non Muslim Dan Perempuan.” AHKAM: Jurnal Ilmu Syariah 17, no. 2 (2017). http://journal.uinjkt.ac.id/index.php/ ahkam/article/view/5204.

Ja'far, Ja'far. "Al Jam'iyatul Washliyah Dan Pelestarian Akidah Ahl Sunnah Wa Al-Jama'ah Di Indonesia." ISLAMICA: Jurnal Studi Keislaman 14, no. 1 (2019). https://doi.org/ 10.15642/islamica.2019.14.1.54-81.

Ja'far, Ja'far. Dewan Fatwa Al Jam'iyatul Washliyah: Sejarah Dan Fatwa-Fatwa. Medan: Dewan Fatwa Al Jam'iyatul Washliyah dan Perdana Publishing, 2020.

Ja'far, Ja'far. "Merantau Demi Republik: Kehidupan Dan Perjuangan Ismail Banda (1909-1951).” Islamijah: Journal of Islamic Social Sciences 1, no. 2 (2020): 136-61. https://doi.org/ 10.30821/islamijah.v1i2.7181.

Ja'far, Ja'far. "Pemikiran Politik Islamisme Moderat Al Jam'iyatul Washliyah." Al-A'raf: Jurnal Pemikiran Islam Dan Filsafat 16, no. 2 (2019). https://doi.org/10.22515/ajpif.v16i2.1762.

Ja'far, Ja'far. "Peran Al Jam'iyatul Washliyah Dalam Merevitalisasi Madhhab Shafi'i Di Era Kontemporer." Justicia Islamica 13, no. 1 (2016). https://doi.org/10.21154/justicia. v13i1.451. 
Ja'far, Ja'far. "Peran M. Arsjad Th. Lubis Dalam Pengembangan Ilmu-Ilmu Keislaman.” Dialogia: Jurnal Studi Islam Dan Sosial 18, no. 2 (2020): 355-76.

Ja'far, Ja'far. "Respons Dewan Fatwa Al Jam'iyatul Washliyah Terhadap Isu Akidah Dan Syariah Di Era Global." Al-Manahij: Jurnal Kajian Hukum Islam, 2017. https://doi.org/ 10.24090/mnh.v10i1.919.

Ja'far, Ja'far. “Tarekat Dan Gerakan Sosial Keagamaan Shaykh Hasan Maksum.” Teosofi: Jurnal Tasawuf Dan Pemikiran Islam 5, no. 2 (2016): 269. https://doi.org/10.15642/ teosofi.2015.5.2.269-293.

Ja'far, Ja'far. “Tradisi Intelektual Ulama Mandailing Abad Ke-20: Dedikasi Dan KaryaKarya Yusuf Ahmad Lubis (1912-1980)." Islamijah: Journal of Islamic Social Sciences 1, no. 2 (2020): 225-47. https://doi.org/10.30821/islamijah.v1i3.7342.

Ja'far, Ja'far. “Ulama Mandailing Awal Abad Ke-20: Gerakan Religius Dan Politik Abdurrahman Sjihab (1910-1955)." Islamijah: Journal of Islamic Social Sciences 1, no. 1 (2020): 1-25. https://doi.org/10.30821/islamijah.v1i1.7155.

Ja'far, Ja'far. “Respons Al Jam'iyatul Washliyah Terhadap Terorisme.” AKADEMIKA: Jurnal Pemikiran Islam 22, no. 1 (2017).

Lubis, M. Arsjad Thalib. "Pembelaan Islam Terhadap Serangan Atheisme." In Muktamar Ulama se-Indonesia di Palembang tanggal 8-11 September 1957. Palembang: Panitia Kongres Alim Ulama Seluruh Indonesia, 1957.

Lubis, M. Arsjad Thalib. Penuntun Perang Sabil, second published. Medan: Firma Madju, 1957.

Lubis, M. Arsjad Thalib. Risalat Djaminan Kemerdekaan Beragama dalam Islam, second published, Medan: Firma Islamiyah, 1961.

Lubis, M. Arsjad Thalib. Kedudukan Kepala Negara Republik Indonesia Ditinjau dari Sudut Hukum Islam. Medan: Pustaka UNIVA, 1967.

Lubis, M. Arsjad Thalib. Pembahasan di Sekitar Nuzul-ul Quran dan Hari-Hari Peringatan Islam, first published. Medan: Firma Islamiyah, 1967.

Lubis, M. Arsjad Thalib. Keesaan Tuhan menurut Adjaran Kristen dan Islam, third published. Jakarta: Hudaya, 1969.

Mubarok, Husni. "Babak Baru Ketegangan Islam dan Kristen di Indonesia." Studia Islamika 21, no. 3, 2014.

Mukani. "Ulama Al-Jawwi di Arab Saudi dan Kebangkitan Umat Islam di Indonesia." Jurnal Al Murabbi 2, no. 2, 2016.

Naseh, Ahmad Hanany. "Nasionalisme dalam Tinjauan Islam.” Jurnal Ulumuddin 4, no. $2,2014$.

Natsir, Muhammad. Capita Selekta 2, second published. Jakarta: PT. Abadi and Yayasan Capita Selekta, 2008.

Noer, Deliar. Gerakan Moderen Islam di Indonesia 1900-1942. Jakarta: LP3ES, 1996. 
MIQOT Vol. 45 No. 1 January-June 2021

Pelly, Usman. "Arsyad Thalib Lubis: Ideolog Masyumi," in H. M. Hasballah Thaib, Syeikh H. M. Arsyad Thalib Lubis Pemikiran \& Karya Monumental. Medan: Perdana Publishing, 2012.

Priangan, Masjoemi. Djihad dan Qitaal. Bandung: Masjoemi Bah. Penerangan Priangan, 1946.

Rozali, M. "Tradisi Dakwa Ulama Al Jam'iyatul Washliyah Sumatera Utara." Jurnal Al Bayan 22, no. 33, 2016.

Rozali, M. "Muhammad Arsyad Thalib Lubis (1908-1972): Ulama yang Membesarkan Al Jam'iyatul Washliyah." Jurnal Studi Multidisipliner 5, no. 1, 2018.

Syahnan, Mhd., Asrul Asrul, and Ja'far Ja'far. "Intellectual Network of Mandailing and Haramayn Muslim Scholars in the Mid-19th and Early 20th Century." TEOSOFI: Jurnal Tasawuf Dan Pemikiran Islam 9, no. 2 (2019). https://doi.org/10.15642/teosofi.2019.9.2.257281.

Syahnan, Mhd., Ja'far Ja'far, and Muhammad Iqbal. "Ulama and Radicalism in Contemporary Indonesia: Response of Al Washliyah's Ulama on Radicalism." AHKAM: Jurnal Ilmu Syariah 21, no. 1 (2021): 89-110.

Thaib, H. M. Hasballah. Syeikh H.M. Arsyad Thalib Lubis Pemikiran \& Karya Monumental. Medan: Perdana Publishing, 2012.

Thaib, H. M. Hasballah. Universitas Al-Washliyah Medan Lembaga Pengkaderan Ulama di Sumatera Utara. Medan: UNIVA, 1993.

Wanto, Sugeng, et.al. "Theological Aspect on Ijtihad of M. Arsyad Thalib Lubis' Thought." Journal of Humanities and Social Science 22, no. 6, 2017.

Zulkifli. "The Ulama in Indonesia: Between Religious Authority and Symbolic Power." MIQOT XXXVII, no. 1, 2013. 